\title{
THREE OLD KINGDOM FRAGMENTARY RELIEFS AND THEIR OWNERS
}

\author{
By

\section{Ibrahim Abd El-Sattar \& Shouikar Salama} \\ Department of History- College of Art- Imam Abdulrahman bin Faisal University- KSA
}

\begin{abstract}
This paper aims to publish three fragments preserved in the archaeological store at Atfiyah and belong to three mastaba tombs at Giza; two of them were mostly collapsed. The importance of this paper is due to that two fragments of those in question only contain the names of their owners [the second and the third fragments], while the first one bears some titles without its owner name. Although two fragments bear the names of their owners, these names were frequently repeated in the Old Kingdom which makes it more difficult to determine their identity. So, identifying the persons who held these names is also the aim of this paper. Accordingly, this paper tries to find out the owners of those fragments and their tombs. After examining the names and the titles inscribed on these fragments and after reconstructing and supplementing the texts of the first fragment, the study concluded that the first fragment belongs to $K_{3}(=j)-h r-P t h: F t k-t 3$ of the Six ${ }^{\text {th }}$ Dynasty, and the owner of the mastaba tomb G 7652 in Giza, while the second fragment is one of the two stelae of ${ }^{n} h \underline{S} \breve{S} p s-k 3=f$ of the Fif ${ }^{\text {th }}$ Dynasty, and the owner of the mastaba tomb G 6040 in Giza. The third fragment is a lintel of $H p-h r-n f r$, the wife of Prj-sn who lived during the middle of the Fif ${ }^{\text {th }}$ Dynasty and the beginning of the Six ${ }^{\text {th }}$ Dynasty. This fragment may have been a part of his mastaba tomb LD 78 in Giza.
\end{abstract}

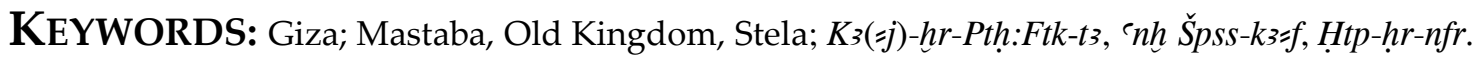




\section{I- INTRODUCTION}

Since many monumental objects are crammed in stores of archaeological sites in Egypt and have not yet been published, their scientific publication will benefit the field of Egyptology and Egyptologists alike. These objects, mostly engraved by sunk or raised hieroglyphic inscriptions and reliefs, will add value to Egyptology. So, the publication of the following three fragmentary reliefs is of similar value for the field, while also having unique importance that stems from the fact that two of these fragments belong to two mastabas tombs which were mostly collapsed, where the third one is a round top-stela, out of a pair, that was moved into the archaeological site of Atfiyah with no further evidence about the current state or location of the pairing stela.

These fragmentary reliefs, being preserved in the storeroom of Atfiyah's archaeological site at Giza [known by inspectors as the storeroom of 'Ali El-Khouli], hold the record numbers 1658-1646 and 1638. Unfortunately, the record register of this storage mentions neither the dating nor any information about the owners of these fragments. However, since some internal attestations refer to Giza as a provenance of these fragments, this paper aims to publish them and to determine the identity of their owners.

\section{II- THE FIRST FRAGMENT}

\section{1- Description [FIGURES 1-2]}

\section{[THE FRAGMENTARY LINTEL OF $K 3(\xi j)-h r-P t h: F t k-t 3]$.}

The first fragment is made of limestone. It is a part of a lintel, measuring $50 \mathrm{~cm}$ in height and $45 \mathrm{~cm}$ in width. It bears the register number 1658, and exhibits an irregular shape inscribed by incised hieroglyphic inscriptions in three partially-erased horizontal lines read from right to left as follows:

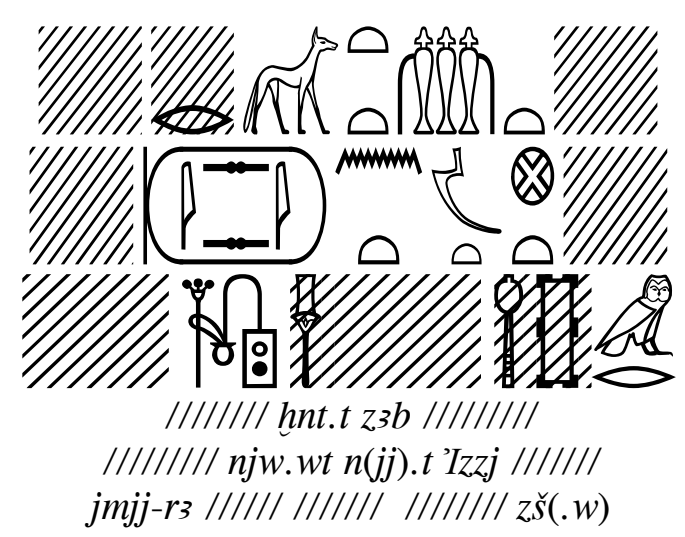

\section{2- Text Reconstruction and Translation}

Despite difficulties in translation that arise from the missing words in these lines, it is not impossible to give an accurate translation PL. 1, [FIGURE 1]

The first line begins with the mono-consonant sign $\circ t$, and is followed by the tri-

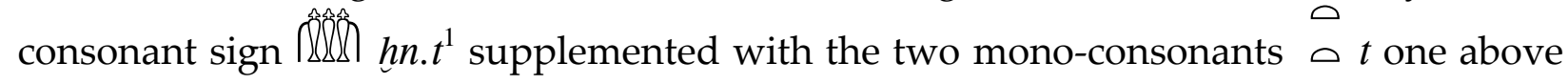


the other. The last sign in this line is the tri-consonant sign- $z 3 b^{2}$ which completes the reading of this line as

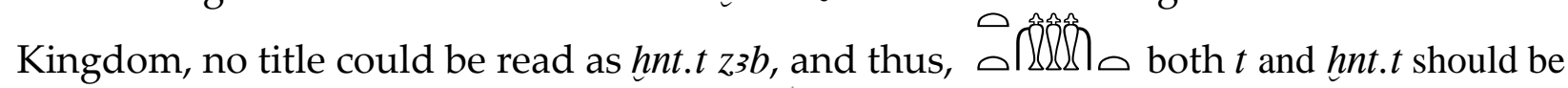
components of one title, while the sign- $z 3 b$ is a part of another one. To provide a complete reading and an accurate translation for this line, the readings of the second and third lines are needed. Consequently, the translation for this line is provided later in the paper.

The second line, on the other hand, is the clearest and can be immediately read as a njw.(w)t mzw.t n(jj).t Izzj. Undoubtedly, this phrase is a part of a title that should be reconstructed as jmjj-r3 njww.t msw.t $n(j j) . t$ Nfr-Izzj [overseer of the new settlements of the pyramid Perfet is $\left.{ }^{\prime} I z z j\right]^{3}$. After examining the names of the Old Kingdom officials who bore this title, it was held by $K_{3}(=j)-h r-P t h$ - whose beautiful name is Ftk-t $3^{4}$ - of the Six ${ }^{\text {th }}$ Dynasty and the owner of the tomb mastaba G5560[LD 35] at Giza $^{5}$.

The third line begins with the two mono-consonants with the bi-consonant $z \tilde{s}^{6}$. It could be also somewhat identifying the sign- $h \underline{d}^{7}$ and

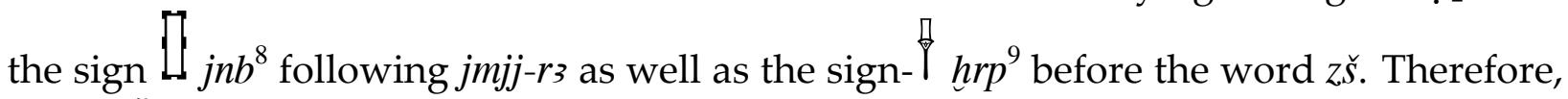
both and are parts of different two titles which can be reconstructed as jmjj-rz jnbw $h \underline{d}$ [Overseer of the Memphite Nomes] ${ }^{10}$ and $h r p z \check{s}(. w)^{I 1}$ [director of scribes] ${ }^{12}$; the two titles are also held by $K_{3}(=j)-h r-P t h: F t k-t{ }^{13}{ }^{13}$. Furthermore, there is a missing part between the sign- 1 and the sign- $P_{\text {that }}$ can be, after studying the titles of $K 3(\xi j)-h r-$ Pth:Ftk-t3, supplemented with the ideogram ${ }^{14}$ which has many supposed readings as $H m / T p-h p s(?)^{15}, j w^{e^{16}}, H m / D w z w \cdot t^{17}$. However, the precise reading is unknown.

${ }^{2}$ GARDINER 1957: S.L. E17.

${ }^{3}$ HeLCK 1957: 126, №. 39; JONES 2000A: 151 (584).

${ }^{4}$ JUNKER 1914: 250; JUNKER 1947: 111[8]; HELCK 1957: 104; JONES 2000A: 151.

${ }^{5}$ JUNKER 1914: 111F; KANAWATI 1977: 123 [375]; ZibeliUs 1978: 111[671]; PIACENTINI 2002: 515, PL. 83.

${ }^{6}$ GARDINER 1957: S.L. Y3.

${ }^{7}$ GARDINER 1957: S.L. T3.

${ }^{8}$ GARDINER 1957: S.L. O36.

${ }^{9}$ GARDINER 1957: S.L. S42.

${ }^{10}$ JONES 2000A: 58 [277]

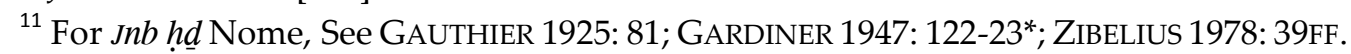

12 JONES 2000B: 739 [2694].

${ }^{13}$ JUNKER 1914: 111[6-7]; DE CENIVAL 1975: 67; ANDRÁSSY 1993: 31 №. 67.

${ }^{14}$ For this hieroglyphic sign and its forms, See MONTET 1957: 49.

${ }^{15}$ For the reading Hm/Tp hpš, See MONTET 1957: 49-56; YOYOTTE 1971: 1; JONES 2000A: 59 [277], 188 [704]. Tp

$n$ hpš. FISCHER 1977: 122; FISCHER 1996: 37. for $H m$ as a name of Letopolis (Modern Ausîm), See Wb vol. 3: 280, 15.

${ }^{16}$ For the reading $h p \check{s} / j w^{c}$, See MONTET 1957: 49.

${ }^{17}$ For the reading $H m / D w 3 w . t$, See GRDSELOFF 1942: 212. 
Accordingly, this title 10 can be read as jmjj-r3 jnb ha Memphite and Letopolite Nomes] $]^{18}$. After comparing the titles of $K_{3}(=j)$ - hr-Pth:Ftk-t3 that were published by Junker ${ }^{19}$ with the titles on our current fragment, the titles in the first line can be reconstructed as 口n seat] ${ }^{20}$ who related to the highest official residence ${ }^{21}$, and administrator] $^{22}$ or two titles $z 3 b$ and jmjj-rz consonant $\odot r$ [with the front part of the owl's claw above it] can be seen to the side of the sign $\hat{\mathbb{N}}$ in the upper left-hand corner. The whole text can be reconstructed, supplemented, and translated as follows:

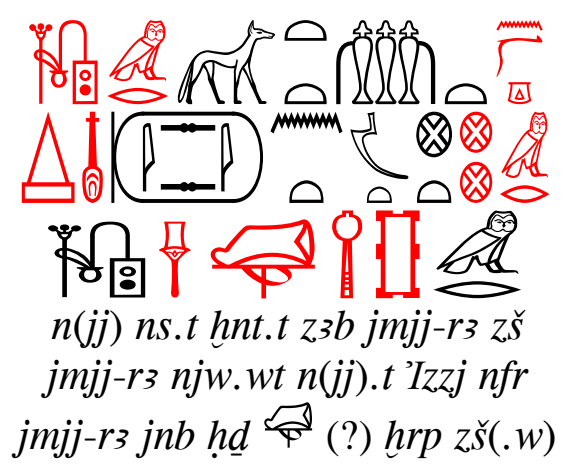

- He who belongs to the foremost seat, the judge, and the overseer of scribes.

- overseer of the new settlements of the pyramid Perfet is ' $I z z j$.

- overseer of the Memphite and Letopolite Nomes, and the director of scribes.

This reconstruction and supplementation are confirmed by a further inscription on a lintel fragment that was reused in mastaba G $7652^{24}$ in the eastern cemetery at Giza ${ }^{25}$ and found by Reisner. This inscription has been reconstructed by Fischer ${ }^{26}$ in a similar manner, with some different, to what was done in the fragment in question.

${ }^{18}$ JUNKER 1914: 111[7].

19 JUNKER 1914: 111.

${ }^{20}$ [The person] who related to the highest official residence. JONES 2000A: 471 [1755].

$n(j j) n s . t$ hnt.t «possessor of a preeminent place» Is the translation of Fischer. FISCHER 1978: 49.

${ }_{21}^{1}$ JUNKER 1914: 111[4]; KANAWATI 1977: 123 [375]; STRUDWICK 1985: 180-81.

22 JUNKER 1914: 111[1]; KANAWATI 1977: 123 [375]; STRUDWICK 1985: 180-81.

${ }_{23}^{23}$ JUNKER 1914: 111[2]; STRUDWICK 1985: 180-81.

${ }^{24}$ The photograph of this inscription is preserved in the records of the Museum of Fine ARTS in Boston. FISCHER 1968: 10, FIG. 3.

${ }^{25}$ FISCHER 1968: 10; STRUDWICK 1985: 154 [150].

${ }^{26}$ FISCHER 1968: 10, №. 47, FIG. 3. 


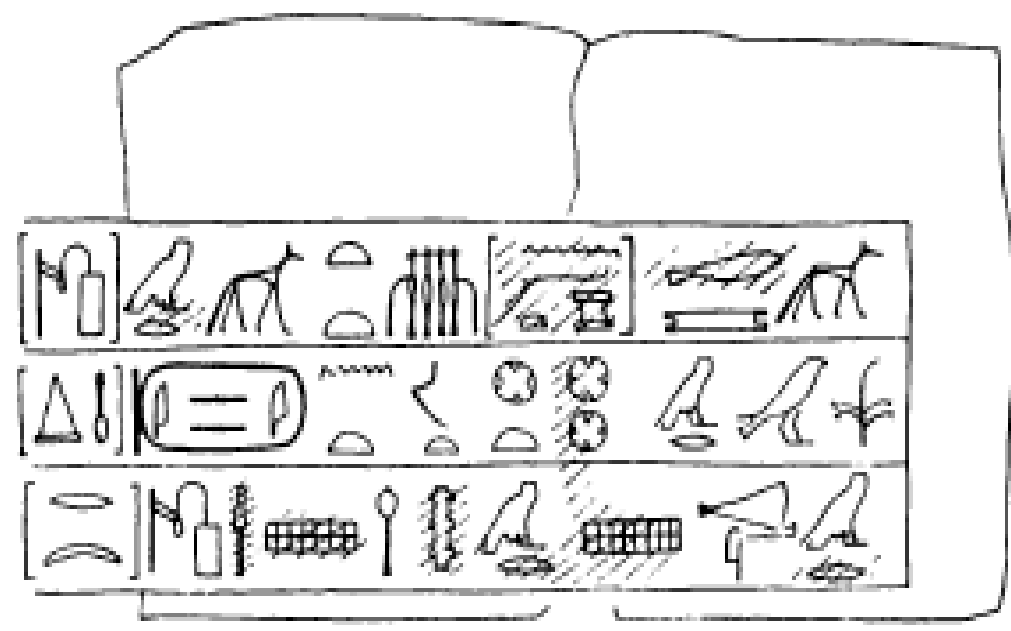

After FISCHER 1968:10, [FIGURE 3]

\section{3- The Names, the Titles, and the Tomb of $K_{3}(-j)-h r-P t h$}

The name of $K 3(=j)-h r$-Pth is listed in both Ranke $P N^{27}$ and Scheele-Schweitzer ${ }^{28}$. It was common in the Old Kingdom ${ }^{29}$ and it can be translated as «My $k_{3}$ is with the god Ptah ${ }^{30}$. The nickname of $K 3(=j)-h r$-Pth or his beautiful name ${ }^{31}$ is $F t k-t 3$ that was common in the Old Kingdom as a person's name or a nickname ${ }^{32}$. This name is translated by Scheele-Schweitzer as «........das Brot», without translation its first component $F t k^{33}$. This name is called on a divine being or minor deity in the Pyramid Texts who is described as $w d p w(n j) R^{`} w$ (Butler/cupbearer of the god Re) ${ }^{34}$. Amer ${ }^{35}$ has discussed the opinions concerning the translation of the name of this deity in the Pyramid Texts and he has argued that this name should be rendered as (Presenter of the bread).

It is clear that $K_{3}(=j)-h r$-Pth:Ftk-t 3 is a high-ranking official in the Old Kingdom, indicated by the titles he held. He bore some judicial offices as represented in the title $z 3 b$ and perhaps the title $n(j j) n s t$ hntt. Strudwick suggests that the association between $n(j j) n s t h n t t$ and the titles $z 3 b$ and $z 3 b \stackrel{c}{ } \mathbf{d}-m r$ gives a sense of a legal nature for the title $n(j j)$ $n s t$ hntt ${ }^{36}$. Moreover, the title $n(j j) n s t$ hntt confirms his position in the royal palace and his closeness to the king tile. In addition to being the overseer of the settlements [villages and domains] ${ }^{37}$ of the pyramid complex of king 'Izzj that gives him the right to supervise all the endowments of the pyramid complex of this king, $K_{3}(=j)-h r$-Pth:Ftk-t3 is

\footnotetext{
27 RANKE 1935: 340 [21].

28 SCHEELE-SCHWEITZER 2014: 708 [3505]. ALTENMÜLLER 1977: TAF. 25.

TAF. 8. 34; BÁRTA 2001: FIG. 3.20.

33 SCHEELE-SCHWEITZER 2014: 366 [1174].

34 PYR: 120A-D,123 G, 545C

35 AMER 2020: 166-167.

36 STRUDWICK 1985: 178-181.

37 ALTENMÜLLER 2002: 25F.
}

${ }^{29}$ DAVIES 1901: PL. XX; BORCHARDT 1911: 169-170 [267]; JUNKER 1950: 76, 78, ABB. 32; 148, ABB. 62; MOUSA \&

${ }^{30}$ RANKE 1935: 340 [21]; SCHEELE-SCHWEITZER 2014: 708 [3505].

31 JUNKER 1914: ABB. 51; RANKE 1935: 143 [2]; SCHEELE-SCHWEITZER 2014: 366 [1175].

32 RANKE 1935: 142 [26]. LD 2: 96; JUNKER 1914: ABB. 51; FISCHER 1976: PL. V; MOUSA \& ALTENMÜLLER 1977: 
also the overseer of the Memphite ${ }^{38}$ and Letopolite Nomes ${ }^{39}$; the first and second Nomes of lower Egypt ${ }^{40}$. Obviously, the two titles $` \underline{d}-m r j n b-\underline{h} \underline{d}$ and $\underline{e}-m r{ }^{41}$ as governors of the Memphite and Letopolite Nomes are lower rank of that of $K_{3}(\xi j)-h r$-Pth:Ftk-tz as the overseer of these two Nomes. The official rank of $K_{3}(=j)$-hr-Pth:Ftk-t3 is higher than a governor of these two Nome, rather, he is their supreme supervisor. On the other hand, another text inscribed on a similar fragment belongs to $K 3(\xi j)-h r-P t h: F t k-t 3$ had been reconstructed by Junker that displays on its first line the title of $K 3(\equiv j)-h r-P t h$ as e $\underline{d}-m r$ $j n b-h \underline{d}$ [governor of the Memphite and Letopolite Nomes] ${ }^{42}$. If this reconstruction is

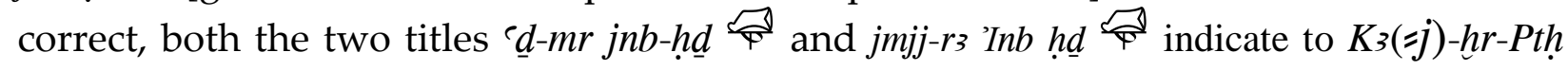
official hierarchy. The latter title is undoubtedly the end of his tenure.

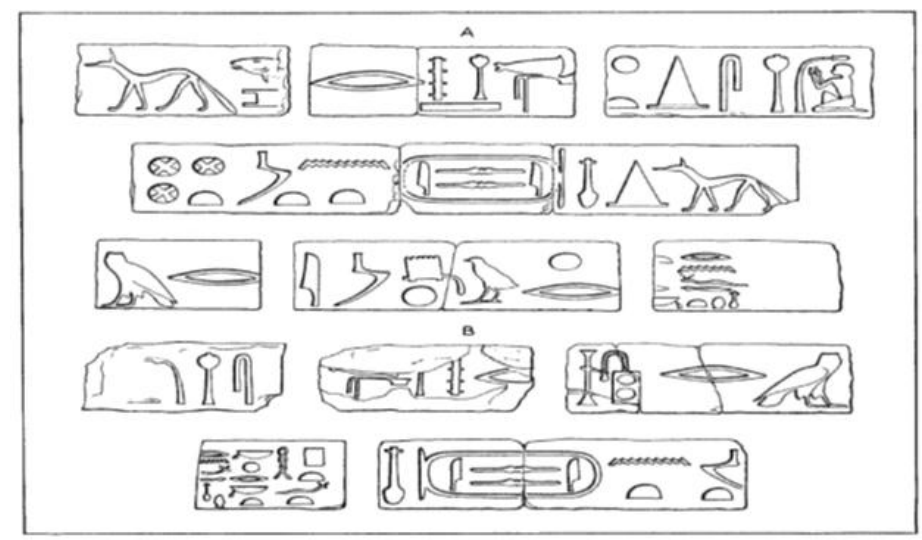

JUNKER 1914: 113, Abb. 51.

The tomb of $K_{3}(=j)-h r-P t h: F t k-t 3$ is located in the western cemetery at Giza, near the temenos wall of the pyramid of Khufu [G 5560= LD 35] $]^{43}$. Bear dates this mastaba to the end of the reign of King Pepi $\mathrm{II}^{44}$, while Strudwick dates it from early to the middle of the Sixth Dynasty ${ }^{45}$. According to Harpur, it is dated between the reign of King Teti and the reign of King Pepi $\mathrm{I}^{46}$. Most of this tomb has been collapsed, leaving just the lower parts of the false doors and a few blocks intact ${ }^{47}$. Most probably, the fragment in question is one of these blocks.

\footnotetext{
${ }^{38}$ WB vol.1: 95, 6; MONTET 1957: 27.

${ }^{39}$ See footnotes (10-11); MONTET 1957: 49-56.

${ }^{40}$ MeMPHIS et All.

${ }^{41}$ For the title $` \underline{d}-m r$, See GoEDICKE 1966: 32.

42 JUNKER 1914: 113, АBB. 51

${ }^{43}$ BAER 1960: 148 [544]; STRUDWICK 1985: 154 [150].

${ }^{44}$ BAER 1960: 148 [544].

${ }^{45}$ STRUDWICK 1985: 154 [150].

${ }^{46}$ HARPUR 1987: 7, 197, 271.

${ }^{47}$ STRUDWICK 1985: 154 [150].
} 


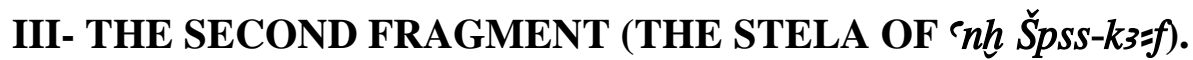 1- Description [FIGURES 3-4]}

The second fragment is a small and thin flat stela with a curved top ${ }^{48}$. It is made of limestone, measuring $59 \mathrm{~cm}$ in height and $37 \mathrm{~cm}$ in width. It bears the register №. 1646 . It is inscribed with sunken hieroglyphic inscriptions in three small horizontal lines, each one contains only one or three words. This short hieroglyphic text gives the title and the

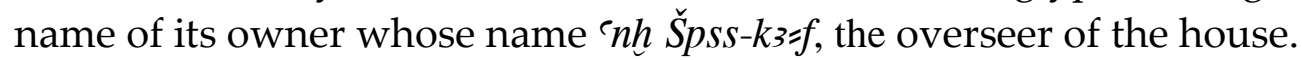

\section{2- Text Translation}

The stela is inscribed by three small horizontal lines read from right to left as follows:

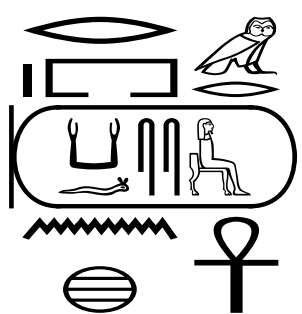

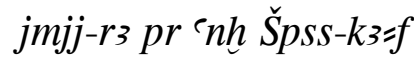

The overseer of the house 'nh $\breve{S} p s s-k 3=f$

\section{3- The Name, the Title, and the Tomb of ' $n h$ Špss-kz=f}

The name of ${ }^{n} n h$ Špss- $k 3=f$ is listed in both Ranke and Scheele-Schweitzer $P N^{49}$. It was common in the Old Kingdom, and it means «May Špss- $k 3=f$ live». Scheele-Schweitzer inventoried all the persons who bear this name ${ }^{50}$ and after investigating their titles, it is concluded that this stela belongs to e $n h \breve{S}$ sss- $k 3=f$ the owner of the nucleus mastaba G $6040^{51}$ [LD 18], which is housed in the west cemetery at Giza ${ }^{52}$ and dated to the Fif ${ }^{\text {th }}$ Dynasty. The texts of this tomb mention only the htp rdj.w njsw.t formula and the title of enh $\breve{S} p s s-k 3=f$ as the overseer of the house of the king ${ }^{53}$ i.e. $N f r-j r-k 3-R^{c^{54}}$. Unfortunately, no more data can be found in his tomb.

\footnotetext{
48 For the rounded-top stela, See MÜLLER 1933: 165-206; PFLÜGER 1947: 127-135; VANDIER 1954: 477, FIG. 293; 485, FIG. 295; WESTENDORF 1966: 40FF, 74FF; HÖLZL 1992: 285; KARL-MARTIN 1986: 1-6; HÖLZL 2001: 320; SHAW \& NICHOLSON 2002: 278.

${ }^{49}$ RANKE 1935: 417 [7]; SCHEELE-SCHWEITZER 2014: 305-306 [750].

50 SCHEELE-SCHWEITZER 2014: 305-306 [750].

For instance, enh Špss-kz=f of the Fif ${ }^{\text {th }}$ Dynasty, and the owner of the mastaba G 1008 at Giza who is titled as $n h t$ hrw z3b (Strong of voice and Judge). REISNER \& FISHER 1914: 244; REISNER 1942: 252 [12]; PM 31: 52. ' $n h \breve{~ S ̌ p s s-k z=f ~ o f ~ t h e ~ e n d ~ o f ~ t h e ~ F i f t h ~ D y n a s t y ~ a n d ~ t h e ~ o w n e r ~ o f ~ t h e ~ m a s t a b a ~ № .9 ~ a t ~ G i z a . ~ H e ~}$ is titled as jmjj-rз $\mathrm{pr}$ [Steward of the house] jmjj-r3 hm.w k3 (Overseer of ka-servants). HASSAN 1950,

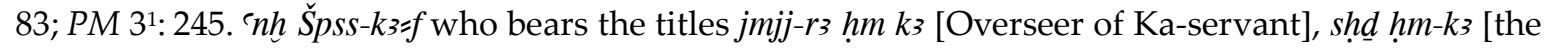
inspector of the Ka-servants], and $h m-n \underline{t} r H^{\complement}=f R^{e}$ [Priest of Khphren] HASSAN 1932: PL. XXIX; HASSAN 1936, FIGS. 22, 25, 27. He was living in the end of the Fif ${ }^{\text {th }}$ Dynasty to the middle of Six ${ }^{\text {th }}$ Dynasty. HASSAN 1932: 15; PM 31: 272. He may be the son of K3-nswt. HASSAN 1936: 75, FIG. 87; WEEKS 1994: FIGS. 31-32, 25.

51 WEEKS 1994: 85FF, FIGS. 53-54.

52 REISNER 1942: 217 [26]; PM 31: 175.

53 WEEKS 1994: PL. 33B, FIGS. 53-54.

${ }^{54}$ REISNER 1937: 30.
} 
As mentioned on this stela, ${ }^{\prime} n h \breve{S} p s s-k 3=f$ bears the title $j m j j-r 3 p r$, which is rendered as [administrator/steward/overseer of the house/estate] ${ }^{55}$. According to Strudwick, this title may relate to some form of non-royal work and probably had a separate existence ${ }^{56}$. The holder of this title is the administrator of the estate of the king or his funerary temple endowments ${ }^{57}$. In the Old Kingdom, the title jmjj-r3 pr was not restricted to overseeing the estate of the king, but it also associated with managing many different institutions ${ }^{58}$ Furthermore, this title continued and its highest rank jmjj-r pr wr in the Middle Kingdom ${ }^{59}$, the New Kingdom ${ }^{60}$, and the Late Period ${ }^{61}$, either in its simple form jmjj-r pr or associating with several institutions ${ }^{62}$.

According to the brief study of Reisner about the tomb of $n h \grave{S} \breve{s} p s-k 3=f$ in 193763 , this stela is one of two rounded-top stelae that were set at the entrance of a sloping ramp [which leads up to this mastaba] and used for the burial procession ${ }^{64}$. Reisner was the first to mention these two stelae, which were found, at that time, in situ on either side of the mastaba65. Unfortunately, these two stelae were extracted from their position with no evidence whether the other stela was preserved in the storeroom of Atfiyah's archaeological site or a further store. These two stelae were a part of the mastaba structure, and they may have been used for the funeral procession ${ }^{66}$. Since the inscriptions on both stelae face to the right, this stela in question is the right one. In a personal communication with Ramadan Hussein, he informed me about his forthcoming publication of mastabas at the Abu Bakr Cemetery at Giza. They have similar ramps, which are in fact a common feature of Giza mastabas. They are located at the back of these mastabas leading up to the burial shaft. He goes on to mention that Reisner found deposits of pottery at the end of such ramps and around the mouth of the burial shafts. Hussein draws the connection between these ramps and pottery deposits on one hand, and the textual reference for the performance of a prt-hrw n.f hr krrt.f $m$ pr $\underline{d} t$ [invocation of offerings on top of his shaft in the house of eternity] ${ }^{67}$. Perhaps this

\footnotetext{
${ }^{55}$ MURRY 1908: PL. XXI; WB I: 514, 10; JONES 2000A: 114 [461]. HASSAN 1932: 7; HASSAN 1941: 14 (4);

HASSAN 1950: 44.

56 STRUDWICK 1985: 235. See also DESPLANCQUES 2006.

57 AL-AYEDI 2006: 33 [131], №. 280.

58 JONES 2000A: 114-134; STRUDWICK 1985: 172FF; DESPLANCQUES 2006: 28, 29, 43, 49, 53, 55, 70, 176, 185, 311, $319,358,385$.

${ }^{59}$ WARD 1982: 21[132], 22 (141).

60 AL-AYEDI 2006: 33 [131], №. 280; CF. The scribe and steward Dhwtjj. URK 4: 336, 2; the steward and the high steward Sn-mwt. URK 4: 381, 17; 395, 2; K3rs. URK 4: 45, 14-15; 46, 8; 47, 13; 48, 10; 49, 10. Sn( (j) jw. ABD EL-SATTAR: 2018, 19. See also. SHIRLEY 2014: 86, 204-205.

${ }^{61}$ For its association with the divine wife, See AYAD 2001: 1-14; AYAD 2007: 1-11.

${ }^{62}$ DESPLANCQUES 2006: 224, 229, 236, 242, 257, 265, 282, 289. 303-304, 332, 379.

63 See footnote 45 .

64 REISNER 1932: 329, PL. 51A.

65 REISNER 1937: 32, FIG. 3.

66 REISNER 1937: 30.

${ }^{67}$ See UrK 1: 189, 15-16 [The tomb of Pth-htp] pr.t hrww $n=f$ hr krr.t $m$ pr $\underline{d} t$ s $\underline{t}$ sw smsw nfr hr Wsjr; Urk 1: 190 910 [The tomb of Tp-m- nh] sje hrr tp krr.t pr.t hrrw n=f; Urk 1: 199, 13 [The tomb of Šsm-nfr-Re/Ššj) pr.t h̆rw n=f

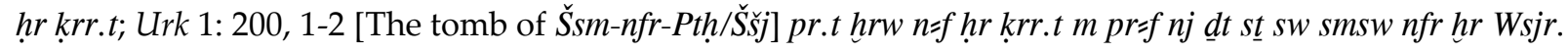


indicates that the ramp was a processional path used during performance of a ritual on top of the shaft.

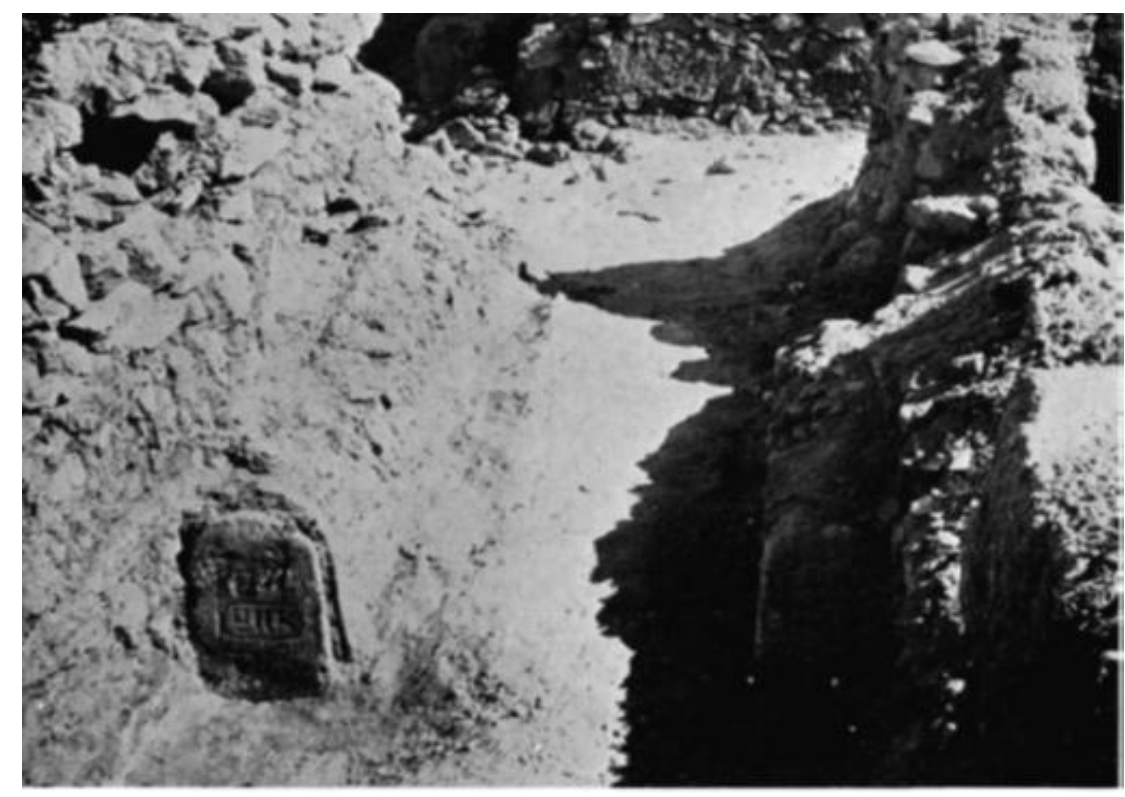

The Ramp and the Two Stelae.

After REISNER 1937: 32, [FIGURE 3].

\section{IV- THE THIRD FRAGMENT}

[The Fragmentary Architrave of $H$ tp- $h r-n f r . t]$.

\section{1- Description [FIGURES 5-6].}

The third fragment is a block made of limestone, measuring $12 \mathrm{~cm}$ in height and 38 $\mathrm{cm}$ in width, and bears the record number 1638. It exhibits a rectangular shape, most likely an architrave with remains of the offering formula htp rdj.w njsw.t ${ }^{68}$.

\section{2- Text Translation}

This architrave is inscribed with sunk hieroglyphic inscription in a horizontal line that read from right to left as follows:

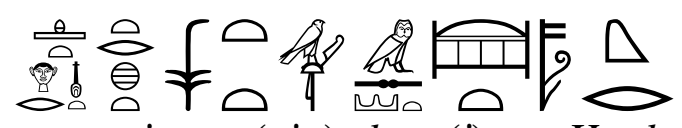

krs.t m zm.t jmnt.t (nj.t) rh.t n(j)sw.t Htp-hrr-nfr.t

A burial in the western necropolis (for) the acquaintance royal $H t p-h r-n f r . t$.

This hieroglyphic line is a part of $h t p-r d j w ~ n j s w . t^{69}$ formula that grants Htp-hr-nfr.t a burial in the western necropolis as a haven for an eternal afterlife. The lost part of this

${ }^{68}$ For this formula, See WAINWRIGHT 1904: 101-104; HALL 1908: 5-7; GARDINER 1915: 79-93; BENNETT 1941 : 77-82; BARTA 1963: 65-67; BARTA 1968; LAPP 1986: 172; BARTA 1987: 7-9; LEPROHON 1990: 163F; SATZINGER 1997: 177-188; FRANKE 2003: 39-57; ILIN-TOMICH 2011: 20-34.

${ }^{69}$ HASSAN 1936: FIG. 63; DUNHAM \& SIMPSON 1974: FIG. 6; WEEKS 1994: FIG. 53; FISCHER 2000: 5, FIG. 2; Vol.6, PL. XXXII.

FIG. 3; BOLSHAKOV 2005: 161, FIG. 11.1, PL. XXXII. 
formula is htp-rdjw njsw.t htp-rdjw 'Inpw, since 'Inpw is the god who always grants the beautiful burial krs.t/ krs.t $n f r$ to the deceased ${ }^{70}$.

A burial or a beautiful burial $\Delta$ बालि is the desire of every deceased ${ }^{71}$, as Pyr. 474a-b mentions: the soul is to the sky; the body is to the earth and the people rmt will receive their burial $k r s^{72}$. The statement $k r s . t=f m$ hr.t $n \underline{t} r$ (zm.t jmn.tt) first appeared in the offering formula in the Fourth Dynasty, indicating to the meaning of «burial» ${ }^{73}$. The trilateral stem $k r s$ and its noun krs.t refer to the meaning of «bury» and «burial» $»^{74}$ respectively that confirmed by using their determinatives $\square$, the word $j z$ «tomb» at the end of the Fif ${ }^{\text {th }}$ Dynasty and as an ideogram of the same word at the end of the Six ${ }^{\text {th }}$ Dynasty ${ }^{75}$.

\section{3- The Name and the Title of Htp-hrr-nfr.t}

The name of $H t p-h r-n f r . t$ is listed in both Ranke $P N^{76}$ and Scheele-Schweitzer ${ }^{77}$. It appeared in the Old Kingdom four times from the Four ${ }^{\text {th }}$ Dynasty to the Six ${ }^{\text {th }}$ Dynasty on the false door stela of $N f r-n t r{ }^{78}$ [Cairo JE. 3520479], in the tomb of Prj-snb [LD 78] [G7901] at $\mathrm{Giza}^{80}$, and on our current fragment. Apparently, the last two examples

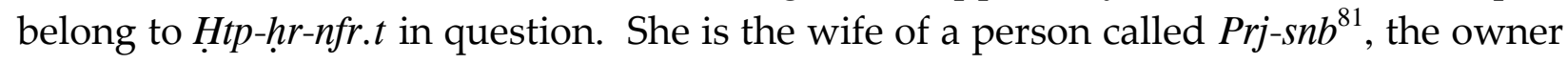
of the mastaba [LD 78] at the eastern cemetery of Giza who lived during the middle of the Fif ${ }^{\text {th }}$ Dynasty and the beginning of the Six ${ }^{\text {th }}$ Dynasty ${ }^{82}$. Most probably, this fragment was an architectural part of his mastaba tomb LD 78 [G 7901] in Giza ${ }^{83}$.

The honorific title $\stackrel{\hat{\theta} \neq}{\text { rh.t }} n(j) s w . t$ first appeared in the Four ${ }^{\text {th }}$ Dynasty ${ }^{84}$. Its orthographical form $\stackrel{\circ}{\ominus} \neq$ is used for a man and a woman alike ${ }^{85}$. Beside its common reading and translation, it has been read by some Egyptologists as jrj $j h(. t) n s w t$ [He belonging to the king] ${ }^{86}$ or $(j) r(j) h(j) n(j)-s w . t$ [He belonging to the baby king] ${ }^{87}$.

\footnotetext{
${ }^{70}$ SMITH 2017: 135.

${ }^{71}$ BORCHARDT 1937: 136, FIG. 34; AHMED 2020: 25, FIG. 2.

72 PYR: 474A-B.

${ }^{73}$ MARIETTE $1885: 88,108,119,130$.

${ }^{74}$ REGEN 2009: 387-399.

${ }^{75}$ RÉGEN 2007: 180, 174, 177.

${ }^{76}$ RANKE 1935: 259 [2].

77 SCHEELE-SCHWEITZER 2014: 569-70 [2596].

${ }_{78}$ BORCHARDT 1937: 137, BLATT. 34, ABB. 1451.

${ }^{79}$ SCHEELE-SCHWEITZER 2014: 570.

${ }^{80} \mathrm{LD}$ vol.2: 94C.

${ }^{81}$ RANKE 1935: 134 [4], 259 [2]; SCHEELE-SCHWEITZER 2014: 358 [111].

82 HARPUR 1987: 266.

${ }^{83} L D$ vol.2: 94C; PM 32: 212.

${ }^{84}$ MarietTe 1885: 88-94; Der MANuelian 2003: Pls. 5-6 (G 1205); Pls. 7-8 (G 1207).

85 FISCHER 1964: FIG. 2, PLS. VII, VIII, IX; EDEL 1980: 52, ABB. 20.

${ }^{86}$ For the reading $j r j j h(. t) n s w . t$, See GOEDICKE 1966: 61-62; GÖDEKEN 1976: 119-124.

${ }^{87}$ BOLSHAKOV 2005: 184.
} 


\section{V-CONCLUSION}

The importance of this article lies in the publication of three fragments of three persons whose tombs have been scattered by small stones and short texts. This helps the editors of the dictionaries of Ancient Egyptians Names and Titles, as well as the Catalogs of Monuments, in listing these pieces with sufficient knowledge that helps the scholars. The first fragment of $K 3(=j)-h r-P t h: F t k-t 3$ demonstrates his high ranking status in the end of the Fif ${ }^{\text {th }}$ Dynasty to the middle of the Six ${ }^{\text {th }}$ Dynasty as the overseer of the Nomes of Memphis and Letopolis, as well as the overseer of the new settlements of the pyramid King 'Izzj. Also, it indicates to his juridical offices and his position in the royal

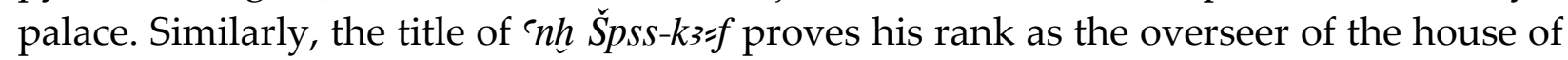
the king $N f r-j r-k 3-R$. This title refers to his office as responsible for the estate of the king. In addition, his stela in question and his missed one reveals that the mastabas in this period had a ramp and probably two stelae led to the top of the burial shaft. They were used for the burial procession and the offering ritual prt-hrw $n . f$ hr krrt.f [invocation of offerings on top of his shaft]. Finally, the fragmentary object of $H t p-h r-$ $n f r . t$ may be a part of the mastaba tomb of her husband Prj-snb.

\section{ACKNOWLEDGMENT}

I would like to thank Dr. Rabiaa Radi for providing me with the photos of these objects and for restoring and cleaning them that made their texts and inscriptions clearer.

\section{HOW TO CITE}

Abd El-Sattar, I. \& Salama, Sh. « Three Old Kingdom Fragmentary

Reliefs and their Owners », Journal of the General Union of Arab Archaeologists, vol. 6/2, 2021. Doi:

10.21608/JGUAA2.2021.45705.1039

iaismail@iau.edu.sa ; smsalama@iau.edu.sa 


\section{THREE OLD KINGDOM FRAGMENTARY RELIEFS AND THEIR OWNERS}

\section{BIBLIOGRAPHY}

AHMED, B.: «Old Kingdom Lintel of Isi at the Egyptian Museum», EJARS 10/1, 2020, 23-27. DOI: 10.21608/EJARS.2020.98958.

AL-CAYEDI, A. R.: Index of Egyptian Administrative, Religious and Military Titles of the New Kingdom, Ismailia (Obelisk Publications) 2006.

AltenMÜLLER, H.: «Presenting the $n$ d.t $h$ hr Offerings to the Tomb Owner», in: BÁRTA, M. (ed.), The Old Kingdom Archaeology. Proceedings of the Conference Held in Prague, May 31-June 4, Prague 2002, 25-35.

CAMER, I.: «The Deity $\Xi_{\theta} \theta$ tk-t3-Ftk-t in the Pyramid Texts», EJARS 10/2, 2020, 165-175. DOI: 10.12608/EJARS.2020.131819.

CAYAD, M.: «Some Thoughts on the Disappearance of the Office of the God's Wife of Amun», JSSEA 28, 2001, 1-14.

: "On the Identity and Role of the God's Wife of Amun in Rites of Royal and Divine Dominion», JSSEA 34, 2007, 1-11.

AbD El-Sattar, I.: «The Anthropoid Wooden Coffin of $S n(=j)-j w$ in Cairo Museum (CG. 61010.1-2)», SHEDET 5, 2018, 17-34. DOI: 10.36816/SHEDET.005.03.

ANDRÁSSY, P.: «Das pr-šn` im Alten Reich», SAK 20, 1993, 17-35.

BAER, K.: Rank and Title in the Old Kingdom, Chicago (University of Chicago Press) 1960.

BARTA, W.: Der Altägyptische Opferliste, MÄS 3, Berlin (Hessling Service) 1963.

: Aufbau und Bedeutung der Altägyptischen Opferformel, ÄF 24, Glückstadt (J.J. Augustin)

1968.

: «Zur Bedeutung der Opferformel im Alten Reich», GM 96, 1987, 7-9.

BÁRTA, M.: Abusir V. The Cemeteries at Abusir South 1, Prague (Czeck Institute of Egyptology) 2001.

BENNETT, C.J.C.: «Growth of the Htp-D'i-Nsw Formula in the Middle Kingdom», JEA 27, 1941, 7782.

BOLSHAKOV, A. O.: Studies on Old Kingdom Reliefs and Sculpture in the Hermitage, ÄA 67, Wiesbaden (Harrassowitz Verlag) 2005.

BORCHARDT, L. D.: Statuen und Statuetten von Konigen und Privatleuten, vol. 1, Catalogue Général des Antiquités Égyptiennes du Musée du Caire $N^{o_{s}}$. 1-1294, Berlin (Reichsdrukerie) 1911.

: Denkmäler des Alten Reiches, vol. I, Catalogue Général des Antiquités Égyptiennes du Musée du Caire Nos 1295-1808, Berlin (Reichsdruckerei) 1937.

BREASTED, G. H.: Ancient Egyptian Records, vol. 1, Chicago (University of Chicago Press) 1900.

DAvies, N. De, G.: Mastaba of Ptahhetep and Akhethetep at Saqqareh, vol. 2, ASE 9, London 1901.

De-Cenival, J. L.: «À Propos de la Stèle de Chéchi. Étude de Quelques Types de Titulatures Privées de l'Ancien Empire», RdÉ 27, 1975, 62-69.

Der MANuelian, P.: Slab Stelae of Giza Necropolis, New Haven and Philadelphia (Yale University Presss) 2003.

DesPlancQues, S.: L'Institution du Trésor en Égypte: des Origines à la Fin du Moyen Empire, Paris (PU ParisSorbonne) 2006.

Dunham, D., \& SIMPSON, W.K.: Giza Mastabas, vol. 1. The Mastaba of Queen Mersyankh III G 75307540, Boston (Museum of Fine Arts) 1974.

EDEL, E.: Hieroglyphische Inschriften des Alten Reiches, Wiesbaden (Literaturverzeichnis - Brill) 1980.

ERMAN, A. \& GRAPOW, H. (eds): Wörterbuch der Ägyptischen Sprache, 5 vols, Leipzig (J. Hinrichs) 1926-1931 [= Wb.].

FISCHER, H. G.: Inscriptions from the Coptite Nome Dynasties VI-XI, AnOr 40, Rome (Pontificium institutum Biblicum) 1964.

: Dendera in the Third Millennium B.C. Down to the Theban Domination of Upper Egypt, New York (J.J. Augustin) 1968.

: Egyptian Studies 1. Varia, New York (The Metropolitan Museum of Art) 1976.

: Egyptian Studies 2. The Orientation of Hieroglyphs, New York (The Metropolitan Museum of Art) 1977.

: «Five Inscriptions of the Old Kingdom», ZÄS 105, 1978, 42-59. 
: Egyptian Studies 3. Varia Nova, New York (The Metropolitan Museum of Art) 1996.

: Egyptian Woman of the Old Kingdom and the Heracleopolitan Period, New York (Metropolitan Museum of Art) 2000.

FRANKE, D.: «The Middle Kingdom Offering Formulas: A Challenge», JEA 89, 2003, 39-41.

GARDINER, A. H.: «The Meaning of the Formula htp dj njswt», In: DAVIES, N. de. G. \& GARDINER, A. H. (eds.), The Tomb of Amenemhat, London (EEF) 1915, 79-93.

: Ancient Egyptian Onomastica, vol. 2, Oxford (Oxford University Press) 1947.

: Egyptian Grammar, 3rd, Oxford (Oxford University Press) 1957.

GAUTHIER, H.: Dictionnaire des Noms Géographiques, vol. 1, Le Caire (IFAO) 1925.

GÖDEKEN, K. B.: Eine Betrachung der Inschriften des Meten im Rahmen der Sozilen und Rechtlichen Stellung von Privatleuten im Agyptischen Alten Reich, ÄA 29, Wiesbaden (Harrassowitz Verlag) 1976.

GOEDICKE, H.: «Die Laufbahn Mțn», MDAIK 21, 1966, 1-71.

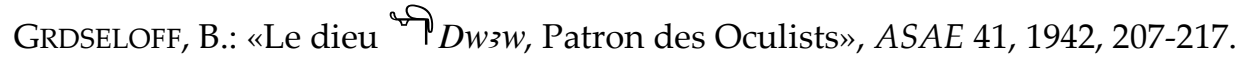

HALL, H. R.: «The hetep-di-suten Formula», PSBA 30, 1908, 5-7.

HARPUR, Y.: Decoration in Egyptian Tombs of the Old Kingdom: Studies in Orientation and Scene Content. Studies in Egyptology, London (KPI) 1987.

HASSAN, S.: Excavation at Giza 1929-1930, vol. 1, Oxford (Oxford University Press) 1932.

: Excavation at Giza 1930-1931, vol. 2, Cairo (Faculty of Arts of the Egyptian University \& Government Press) 1936.

: Excavations at Gîza 1931-1932, vol. 3, Cairo (The Faculty of Arts, Fouad I University) 1941.

: Excavations at Giza 1934-1935, vol. 4/3, Cairo (Faculty of Arts of the Egyptian University \& Government Press) 1950.

HeLCK, W.: Untersuchungen zu den Beamtentiteln des Ägyptischen Alten Reiches, ÄF 18, Gluckstadt (J.J. Augustin) 1954.

: «Bemerkungen zu den Pyramidenstäden im Alten Reich», MDAIK 15, 1957, 90-111.

HöLzL, R.: «Rounded-Topped Stelae from the Middle Kingdom to the Late Period. Some Remarks on the Decoration of the Lunettes», in Sesto Congersso Internazionale di Egittologia, vol. 1, Atti, 1992, 285-290.

: «Stelae», The Oxford Encyclopedia of Ancient Egypt, vol. 3, Oxford (Oxford University Press) 2001, 319-324.

JONES, D.: An Index of Ancient Egyptian Titles, Epithets and Phrases of The Old Kingdom, vol. 1, Oxford (BAR International Series 866) 2000A.

: An Index of Ancient Egyptian Titles, Epithets and Phrases of the Old Kingdom, vol. 2, Oxford (BAR International Series 866) 2000B.

JUNKER, H.: «The Austrian Excavations, 1914. Excavations of the Vienna Imperial Academy of Sciences of the Pyramids at Gizah», JEA 1/1, 1914,250-253.

: Gîza VIII², Der Ostabschnitt des Westfriedhofs, Wien (Adolf Holzhausens) 1947.

: Gîza IX, Das Mittelfeld des Westfriedhofs, Wien (Adolf Holzhausens) 1950.

: Gîza IX, Das Mittelfeld des Westfriedhofs, Wien (Adolf Holzhausens) 1950.

KARL-MARTIN, G.: «Stele», LÄ 6, Wiesbaden (Harrassowitz Verlag) 1986, 1-6.

KANAWATI, N.: The Egyptian Administration in the Old Kingdom, Warminster (Aris \& Phillips) 1977.

Ilin-TOMich, A.: «Changes in the htp-dj-nsw Formula in the Late Middle Kingdom and Second Intermediate Period», Z $\ddot{A} S$ 138, 2011, 20-34.

LAPP, G.: Die Opferformel des Alten Reiches, Mainz (Philipp von Zabern) 1986.

LEPROHON, R.J.: «The Offering Formula in the First Intermediate Period», JEA 76, 1990, 163-64.

LEPSUIS, C. R.: Denkmäler aus Aegypten und Aethiopien, vol. 2, Genéve (Belles-Lettres of Geneva) 1972 $[=\mathrm{LD}$ 2.].

MARIETTE, A.: Les Mastaba de AEmpire, Paris (F. Vieweg) 1885.

MONTET, P.: Geographie de l'Égypte Ancienne, vol. 1, Paris (Imperimerie Nationale) 1957. 


\section{THREE OLD KINGDOM FRAGMENTARY RELIEFS AND THEIR OWNERS}

MousA, A. M. \& AltenmülleR, H.: Das Grab des Nianchchnum und Chnumhotep, AV 21, Mainz (Verlag Philipp von Zabern) 1977.

MÜLlER, H. W.: «Die Totendenksteine des Mittleren Reiches, ihre Genesis, ihre Darstellungen und ihre Kompsition», MDAIK 4, 1933, 165-206.

Murry, M. A.: Index of Names and Titles of The Old kingdom, London (Office of British School of Archaeology) 1908.

PfLÜGER, K.: «The Private Stelae of the Middle Kingdom and Their Importance for the Study of Ancient Egyptian History», JAOS 67/2, 1947, 127-135.

RANKE, H.: Die Ägyptischen Personennamen, vol. 1, Glückstadt (J.J. Augustin) 1935.

REGEN, I.: «À Propos des Graphies de jz/js "Tombe"», BIFAO 107, 2007, 171-200

: «À Propos du Sens de qrs "Enterrer"», Verba Manent, Cahiers de l'ENIM 2/2, 2009, 387-399.

REISNER, G. A. \& FISHER, C. S.: «Preliminary Report on The Work of the Harvard- Boston Expedition», ASAE 13, 1914, 227-252. : «The Position of Early Grave Stelae», in: Glanville, S. R. K. (ed.), Studies Presented to F.

LL. Griffith, Oxford (Oxford University Press) 1932, 324-331. : «A Family of Royal Estate Stewards of Dynasty V», BMFA 37 №. 220, April 1937, 2935.

: A History of Giza Necropolis, vol. 1, Cambridge (Harvard University Press) 1942.

SATZINGER, H.: «Beobachtung zur Opferformel: Theorie und Praxis», LingAeg 5, 1977, 177-188.

SCHEELE-SCHWEITZER, K.: Die Personennamen des Alten Reiches. Altägyptische Onomastik unter Lexikographischen und Sozio-kulturellen Aspekten, Philippika 28, Wiesbaden (Harrassowitz Verlag) 2014.

SETHE, K.: Urkunden der 18. Dynastie, Leipzig (J. C. Hinrichs) 1906 [= Urk 4.].

: Die Altägyptischen Pyramidentexten, 2 vols, Leipzig (J. C. Hinrichs) 1908-1910[= Pyr.].

: Urkunden des Alten Reichs, Leipzig (J. C. Hinrichs) 1933 [= Urk 1.].

SHAW, I., \& NichOLSON, P.: «Stelae», The British Museum Dictionary of Ancient Egypt, Cairo (British Museum) 2002, 270.

SHIRLEY, J. J.: «The Power of the Elite: The Officials of Hatshepsut's Regency and Coregency», In Creativity and Innovation in the Reign of Hatshepsut, edited by GALÁN, J. M., Occasional Proceedings of the Theban Workshop, SAOC 69, 2014, 173-245.

SIMPSON, W.: Giza Mastabas, vol. 4/1. Mastabas of the Western Cemetery, Boston (Museum of Fine Arts) Boston, 1980.

SMITH, M.: Following Osiris. Perspective on the Osirian Afterlife from Four Millennia, Oxford (Oxford University Press) 2017.

STRUDWICK, N.: The Administration of Egypt in The Old Kingdom. The Highest Titles and Their Holders, London (KPI) 1985.

Piacentini, P.: Les Scribes dans la Société Egyptienne de l'Ancien Empire, vol. 1, Études el Mémories d'Égyptologie 5, Paris 2002.

PORTER, B. \& MOss, R. L. B.: Topographical Bibliography of Ancient Egyptian Hieroglyphic Texts, Reliefs, and Paintings, III', Saqqara to Dahshur, Oxford (Clarendon Press) 1981. [= PM 32.].

VANDIER, J.: Manuel d'Archéologie Égyptienne, vol. 2/1, Paris (A. et J. Picard) 1954.

WAINWRIGHT, G. A.: «The Formula htp-dì nsw in the Light of Mythology», PSBA 26, 1904, 101-104.

WARD, W. A.: Index of Egyptian Administrative and Religious Titles of The Middle Kingdom, Beirut (American University of Beirut) 1982.

WeEKS, K. R.: Giza Mastabas, vol. 5. Mastabas of Cemetery G 6000, Boston (Boston Museum of Fine Arts) 1994.

WESTENDORF, W.: Ägyptische Darstellungen das Sonnenlaufes der Abschüssigen Himmelsbahn, MÄS 10, Berlin (Hessling Service) 1966.

YOYOTTE, J.: «La Localisation de Ouenkhem», BIFAO 71, 1971, 1-10.

ZiBELIUS, K.: Ägyptische Siedlungen nach Texten des Alten Reiches, Beihefte zum Tübinger Atlas des Vorderen Orients 19, Wiesbaden (Reichert Services) 1978. 


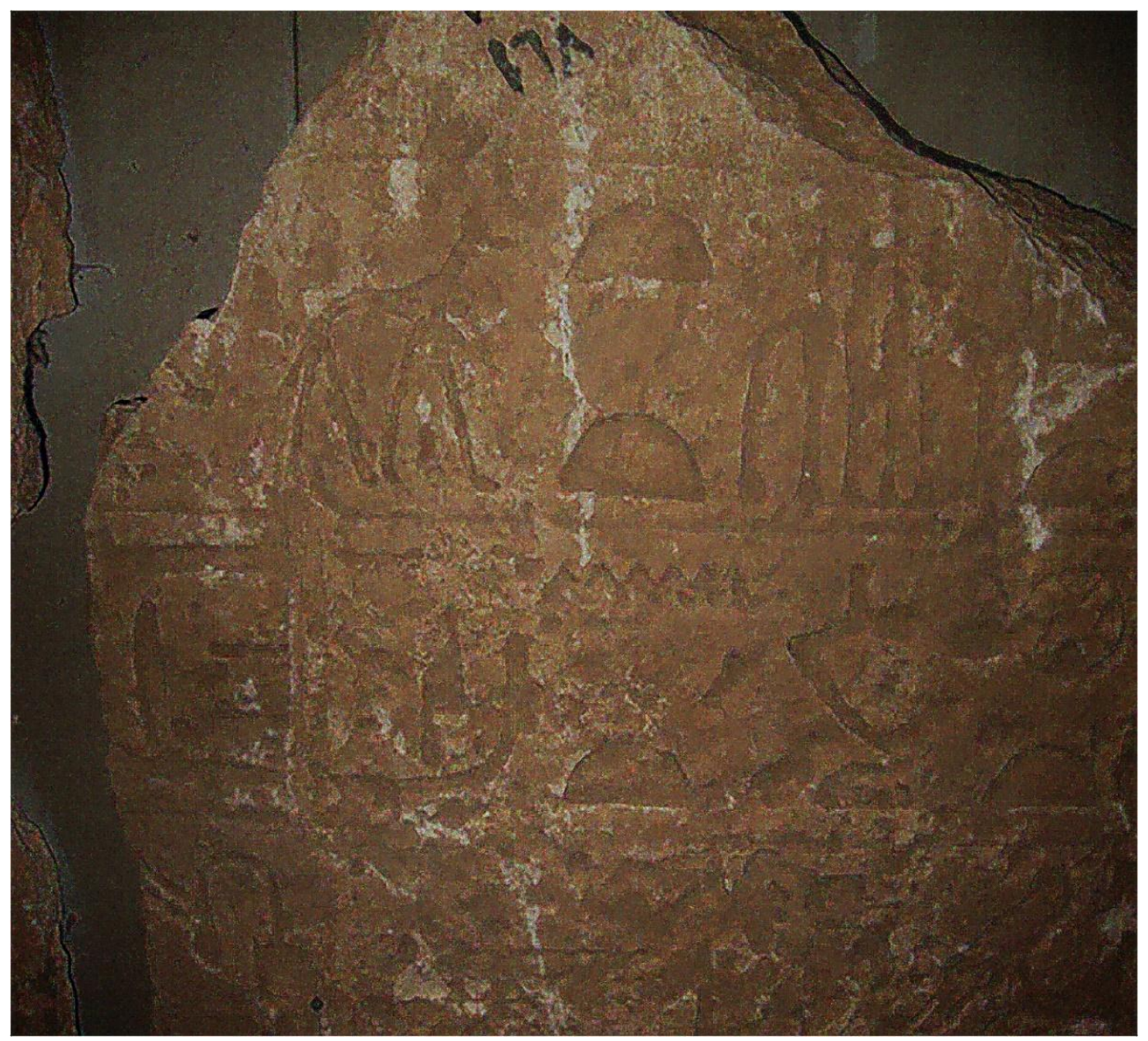

[FIGURE 1]: The lintel Fragment of $K_{3}(=j)-h r-p t h$, F $t k-t_{3}$ OPhoto taken by dr. Rabiaa Radi

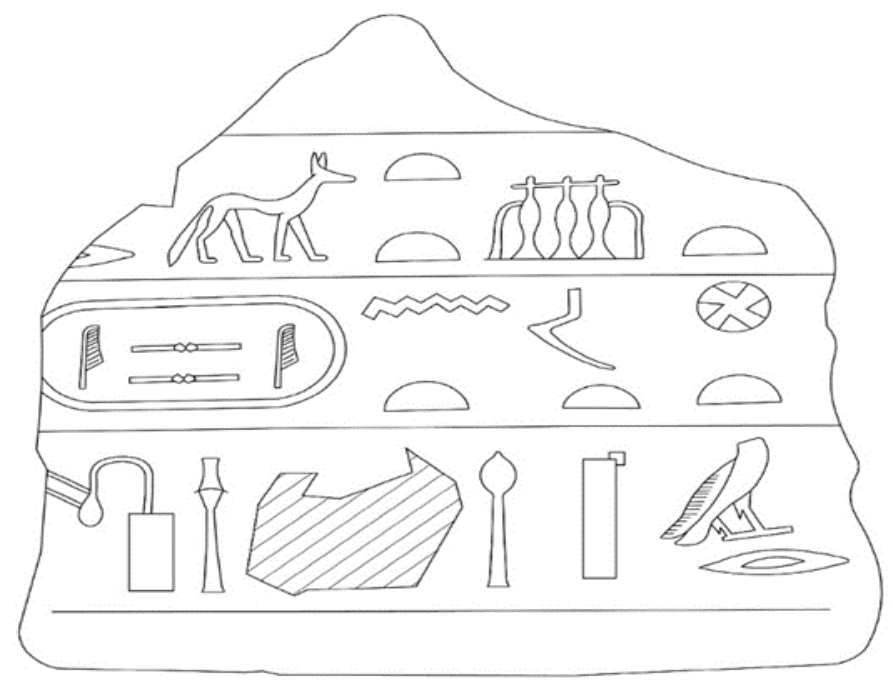

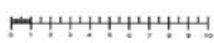

[FIGURE 2]: The lintel Fragment of $K_{3}(\xi j)-h r-p t h, F t k-t 3$ CDone by Mohamed Ibrahim 


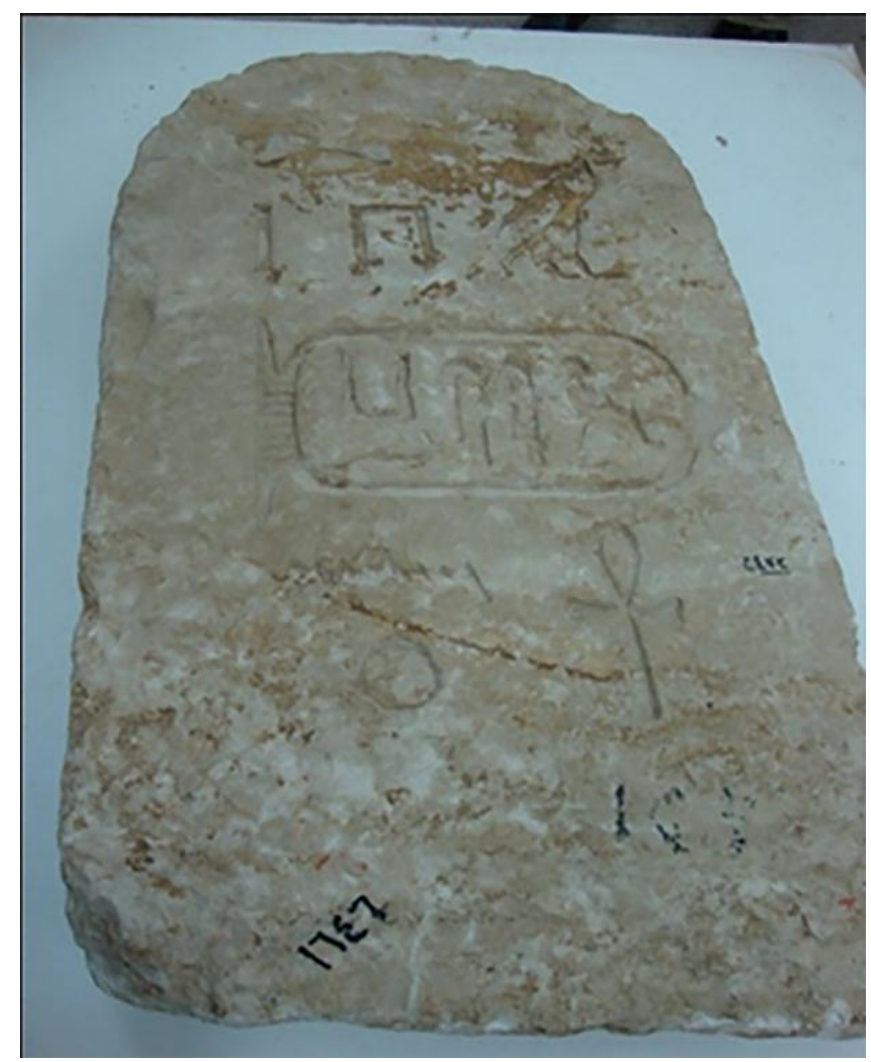

[FIGURE 3]: The Rounded-top Stela of 'nh Špss-k3=f @Photo taken by dr. Rabiaa Radi

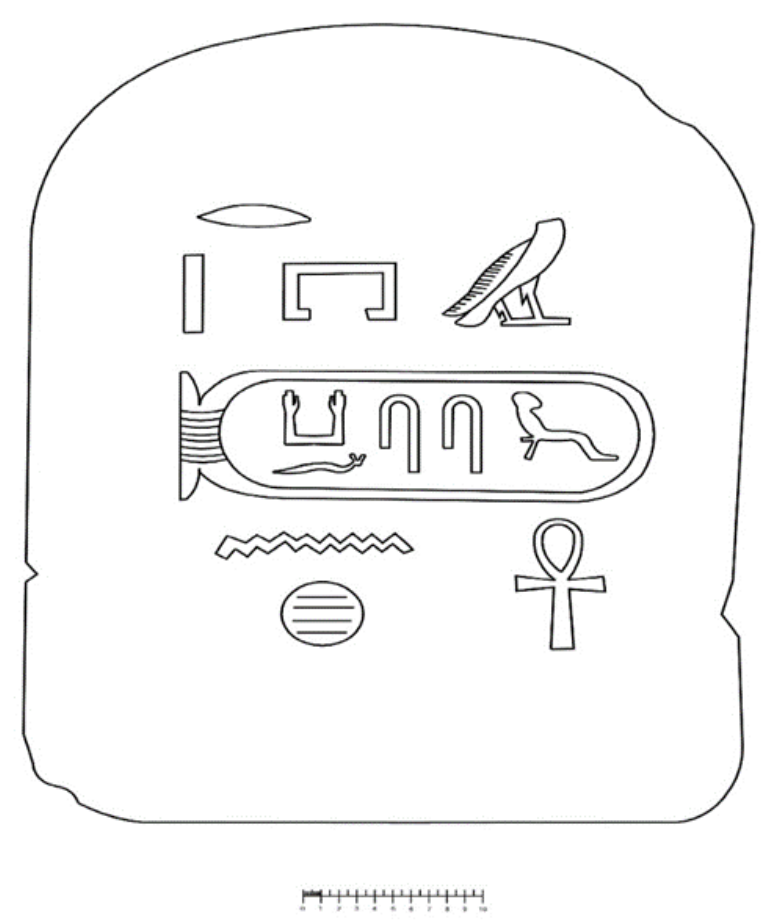

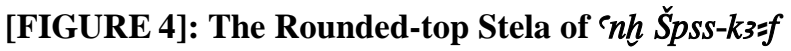
CDone by Mohamed Ibrahim 


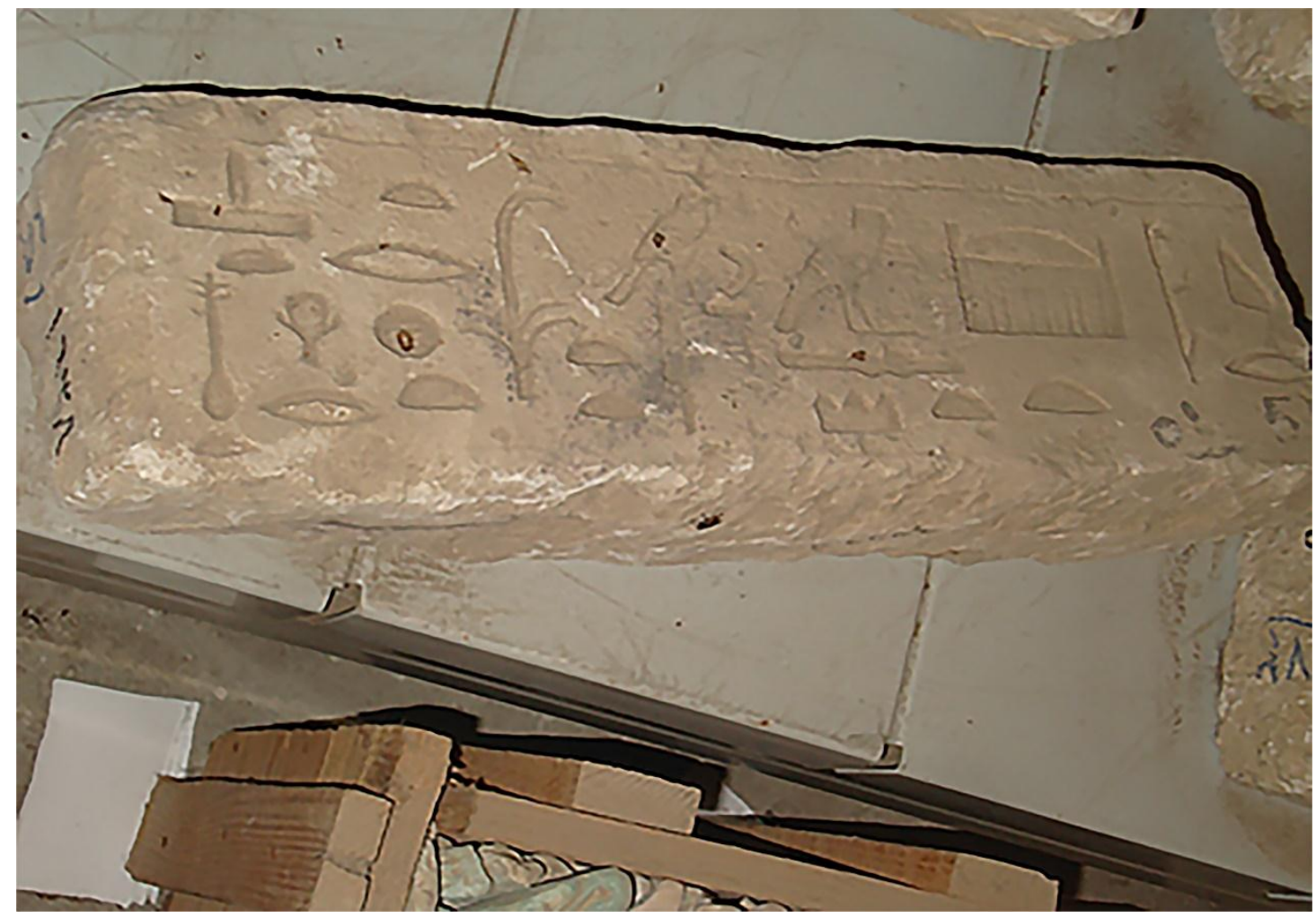

[FIGURE 5]: The Architrave fragment of $\boldsymbol{H} t p-h r-n f r . t$

Photo taken by dr. Rabiaa Radi

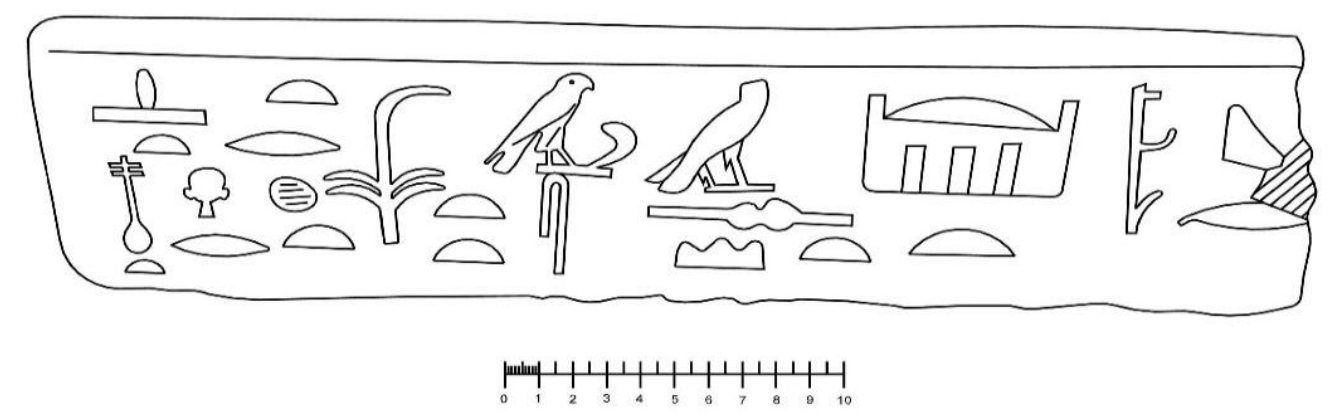

[FIGURE 6]: The Architrave fragment of $H t p-h r-n f r . t$ CDrawn by Mohamed Ibrahim 


\title{
ثلاثة بقايا لقطع منقوشة من الدولة القديمة ومالكيها
}

\section{د. إبراهيم عبد الستار إبراهيم و أ.د/ شويكار سلامة}

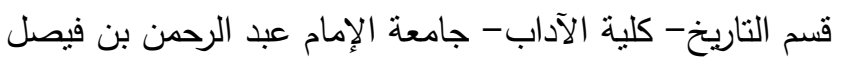

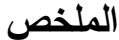

تهدف تلاك الورقة البحثية إلى نشر ثلاثة قطع محفوظة بمخزن الآثار فى أطفيح، وتتنمي إلى بقايا ثلاثة مقابر تهدمت

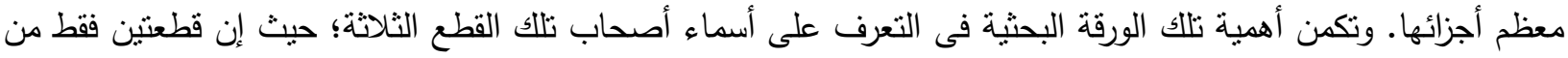
تلالك القطع الثلاثة تحمل أسماء مالكيها (القطعتين الثانية والثالثة)، بينما القطعة الأولى تحمل بقايا ألقاب بدون أى اسم يدل على صاحب تلك القطعة. وتزداد المشكلة أن نلك الأسماء تكرر ظهورها كثيرًا فى الدولة القديمة. وبعد فحص الألقاب والأسماء

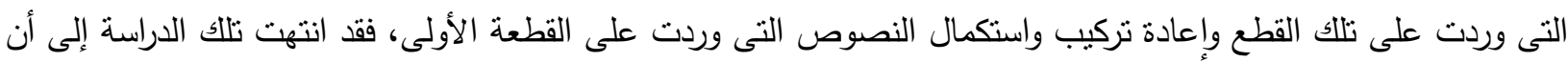
القطعة الأولى تخص المدعو "كا خر بتاح فتلك تا" من الأسرة السادسة، وصاحب المقبرة G 7652 بالجيزة، بينما القطعة

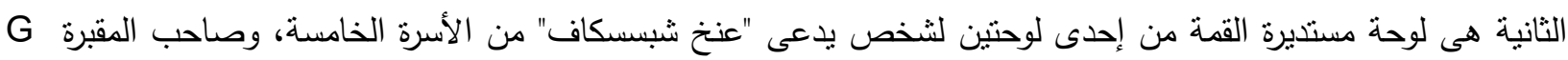

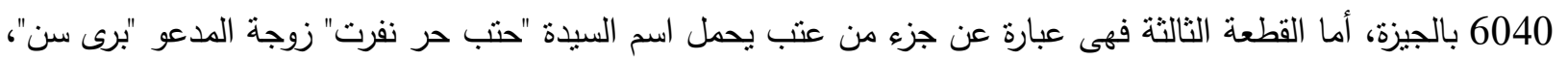

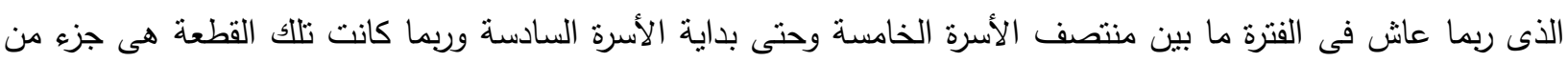

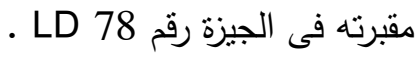

الكلمات الدالة:الجيزة، حتب حر نفرت، الدولة القديمة، عنخ شبسكاف، كا خر بتاح، لوحة، مصطبة. 